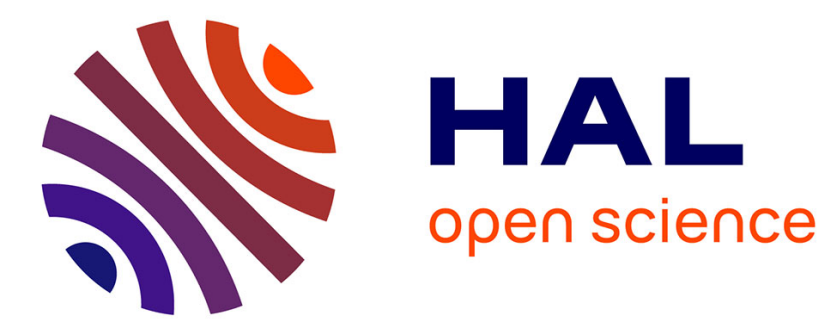

\title{
Call for Papers for a Special Issue of Group Processes \& Intergroup Relations in Intergroup Emotions
}

\author{
Roger Giner-Sorolla, Eliot R. Smith, Diane Mackie
}

\section{To cite this version:}

Roger Giner-Sorolla, Eliot R. Smith, Diane Mackie. Call for Papers for a Special Issue of Group Processes \& Intergroup Relations in Intergroup Emotions. Group Processes and Intergroup Relations, 2005, 8 (4), pp.470-470. 10.1177/1368430205060648 . hal-00571617

\section{HAL Id: hal-00571617 https://hal.science/hal-00571617}

Submitted on 1 Mar 2011

HAL is a multi-disciplinary open access archive for the deposit and dissemination of scientific research documents, whether they are published or not. The documents may come from teaching and research institutions in France or abroad, or from public or private research centers.
L'archive ouverte pluridisciplinaire HAL, est destinée au dépôt et à la diffusion de documents scientifiques de niveau recherche, publiés ou non, émanant des établissements d'enseignement et de recherche français ou étrangers, des laboratoires publics ou privés. 


\section{CALL FOR PAPERS}

\section{Group Processes and Intergroup Relations}

\section{Special Issue: Intergroup Emotions}

\section{Guest Editors:}

Roger Giner-Sorolla (University of Kent), Eliot R. Smith (Indiana University), and Diane Mackie (University of California, Santa Barbara)

Group Processes and Intergroup Relations seeks submissions for a special issue on the social psychology of Intergroup Emotions.

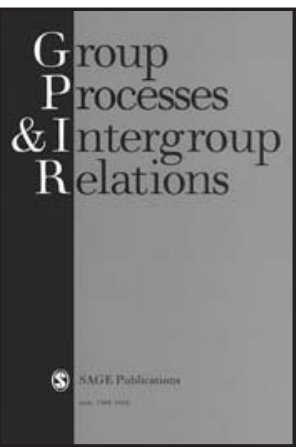
Submissions should capture new directions, report empirical studies, and focus on specific emotions rather than generalized affect.

The past decade has seen a rapid increase in research on differentiated emotions within intergroup attitudes and behavior. While numerous new theoretical approaches and research paradigms have emerged, focusing on topics ranging from automaticity in intergroup emotions to perception of emotions in outgroups, there is still great potential for advances in this field of inquiry. This special issue of GPIR is an opportunity to assemble research contributions and capture exciting new directions in this growing field.

Empirical papers that are theory-based and represent meaningful advances over previous work are sought. To fit the issue's theme, papers should examine the role of specific emotions (as opposed to generalized positive or negative affect) in reactions toward, or relations between, social groups. Although all submissions fitting these criteria will be considered, we take special interest in contributions that support the "new directions" focus, either by looking at emotions not previously examined in group contexts, or by expanding the scope of enquiry beyond the circumstances under which intergroup emotions arise: for example, seeing how emotions influence behavior, or applying larger issues from emotion theory to the intergroup context.

Submissions should be made electronically (Word or RTF files) to the GPIR Journal Office in Kent: gpir@kent.ac.uk. In the submission letter, indicate that the MS is submitted for consideration for publication in the Special Issue on Intergroup Emotions. Please direct inquiries to the guest editors: Roger Giner-Sorolla, r.s.giner-sorolla@kent.ac.uk, Eliot R. Smith, esmith4@indiana.edu, and Diane Mackie, mackie@psych.ucsb.edu.

\section{The deadline for submissions is December 1st 2005.}

GPIR is edited by Dominic Abrams and Michael Hogg, and is published by SAGE. It is a quarterly social psychology journal that publishes empirical, theoretical and review articles on any aspects of social behavior related to group membership, collective self-conception, and occurring in or between groups.

For full details about the journal and submission of manuscripts please visit: http://gpi.sagepub.com

\section{(SAGE Publications}

